\title{
Hakim Perempuan Dalam Perspektif Islam
}

\author{
Muhammad Aiz, M. H \\ STIT Al Marhalah Al Ulya Bekasi \\ Email: anisbata124@gmail.com
}

\begin{abstract}
This article proves that an existence of women as a judges has continuously became a debatable issue. Furthermore this article agrees with Ibn Jari $>r$ al-T\}abari> that allows men and women to become muftis or judges. This article is in line with Euis Nurlaelawati and Arskal Salim's argument stating that the high sensitivity of women judges may lead to problem in judges decision making. This research used normative approaches, that may applied and analyzed based on related laws and regulations.
\end{abstract}

Keywords: Judges, Women, Religious Court, Islamic Law.

\section{Pendahuluan}

Kedudukan seorang hakim sangatlah penting dan menentukan dalam penyelesaian sebuah kasus. Oleh karena itu posisi hakim sangatlah strategis dalam menentukan nasib seseorang maupun kelompok manusia. Begitu pentingnya kedudukan seorang hakim menjadikan persyaratan-persyaratan yang harus dipenuhi oleh seseorang yang hendak diangkat menjadi seorang hakim sangat ketat.

Persyaratan yang telah ditentukan oleh para ulama sesungguhnya bermuara dari ayat-ayat al-Qur'an dan hadis . Pemahaman serta penafsiran dari para ulama tersebut tentunya tidak dapat dihindarkan dari pengaruh budaya, sosial, bahkan politik ketika itu. ${ }^{1}$ Adanya perbedaan pendapat dikalangan umat Islam terkait dengan kebolehan seorang perempuan menjadi hakim sesungguhnya bermuara dari adanya perbedaan penafsiran dari ayat alQur'an ${ }^{2}$ maupun hadis nabi Muhammad SAW ${ }^{3}$. Kuatnya budaya patriarki

\footnotetext{
1. Khoirudin Nasution, Fazlur Rahman tentang Wanita, (Yogyakarta:Tazzafa,2002), hlm. 43.

${ }^{2}$. Lihat Q.S 4:34 yang menyebutkan bahwa laki-laki sebagai pemimpin perempuan.
} 
menjadi pintu masuk dalam proses penfasiran ayat maupun hadis sehingga mengkibatkan termarginalkannya perempuan dalam berbagai aspek kehidupan termasuk dalam porsi kesempatan untuk menduduki posisi seorang hakim. ${ }^{4}$

Terkait dengan persyaratan untuk dapat menjadi seorang hakim. para ulama berselisih pendapat tentang menentukan bilangan syarat-syarat yang harus dimiliki oleh seorang hakim (qadi). Tetapi, mereka saling melengkapi satu sama lain. Menurut Al-Ramli ada 10 syarat menjadi hakim dan pendapat ini didasarkan kepada Imam Al-Nawawi, yaitu Islam, mukallaf, merdeka, laki-laki, mendengar, melihat, berkata-kata, kemampuan dan mujtahid. Sedangkan Al-Mawardi mensyaratkan 7 ketentuan, yaitu laki-laki, berakal, merdeka, Islam, adil, sejahtera pendengaran dan penglihatan, dan menguasai bidang hukum syara'. Jika diteliti maka syarat-syarat yang dikemukakan oleh kedua pakar ini tidak mempunyai perbedaan dan saling melengkapi satu sama lain.

Salah satu persyaratan yang akan dibahas dalam makalah ini adalah terkait masalah apakah memang hanya laki-laki yang dapat menjadi hakim. Tentu pertanyaan ini akan sangat bias gender apabila dikaji berdasarkan kesetaraan manusia di mata Allah SWT.

3

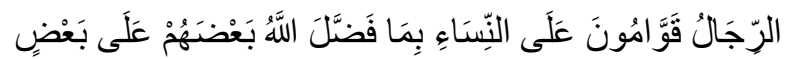

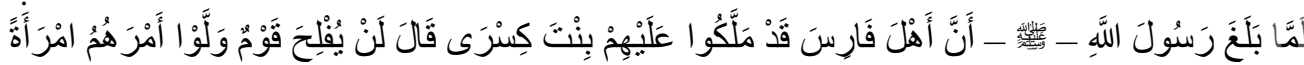
Tatkala ada berita sampai kepada Nabi shallallahu 'alaihi wa sallam bahwa bangsa Persia mengangkat putri Kisra (gelar raja Persia dahulu) menjadi raja, beliau shallallahu 'alaihi wa sallam lantas bersabda, "Suatu kaum itu tidak akan bahagia apabila mereka menyerahkan kepemimpinan mereka kepada wanita". (HR. Imam al-Bukhari No. 4425).

Hadis ini sesungguhnya mendapat kritikan atas kesahihannya. Hal ini dikarenakan adanya salah satu perawi yang bernama Abu Bakrah yang dianggap lemah karena pernah berdusta tentang perzinahan di masa Khalifah Umar bin Khattab. Namun dalam pengkajian selanjutnya, nama Abu Bakrah dianggap dapat dipercaya sebagaimana termaktub dalam kitab Tahdib al-Kamal fi Asma al-Rijal, Tabaqat Ibnu Sa'ad, Al-Kamil fi al-Tarikh Ibn Athir. ${ }^{4}$. Djazimah Muqoddas, Kontroversi Hakim Perempuan pada Peradilan Islam di Negaranegara Muslim, (Yogyakarta: LKis, 2011). 


\section{Sejarah Kekuasaan Kehakiman di Masa Rasulallah SAW}

Lembaga kekuasaan kehakiman, atau yang dikenal dengan lembaga peradilan, sesungguhnya telah ada sebelum datangnya Islam. Ketika datangnya Islam, maka salah satu persoalan yang mendapat perhatian Nabi Muhammad SAW adalah peradilan. Hal ini dapat dilihat dengan adanya beberapa hadis Nabi Muhammad SAW yang secara jelas menerangkan pentingnya posisi seorang hakim serta ancaman apabila dalam memutuskan perkara terindikasi ketidakjujuran. ${ }^{5}$

Pada masa awal masa kekuasaan Islam, kembaga peradilan masih berada di bawah kewenangan langsung Nabi Muhammad SAW. Nabi lah yang melaksanakan fungsi sebagai hakim atas berbagai persoalan dan sekaligus sebagai pemimpin umat. Setelah Islam mulai berkembang dan kekuasaan Islam makin meluas, Nabi Muhammad SAW mulai mengangkat sahabat-sahabatnya untuk menjalankan kekuasaan dibidang peradilan di berbagai tempat. Di antara sahabat tersebut adalahMuadh bin Jabal RA, yang ditunjuk menjalankan kekuasaan pemerintahan dan peradilan di negeri Yaman, serta Atab bin 'Asid yang menjadi hakim di Mekah. ${ }^{6}$ Dengan demikian dapatlah kita menetapkan bahwa hakim pertama di dalam Islam ialah Nabi Muhammad SAW sendiri. Nabi Muhammad SAW sendiri melaksanakan peranannya sebagai hakim setelah menerima firman Allah

\footnotetext{
5

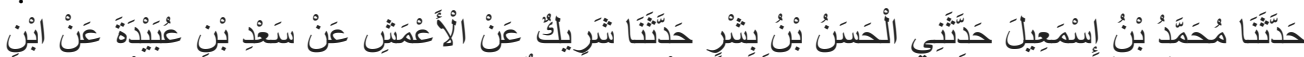

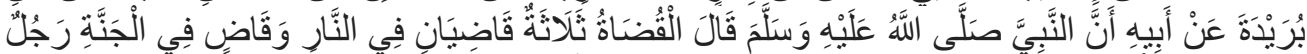

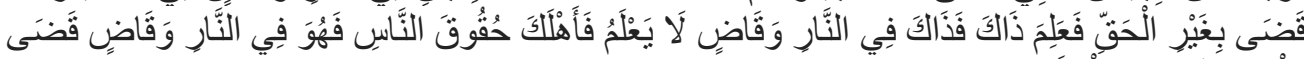

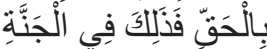

Hakim itu ada tiga, dua di neraka \& satu di surga: seseorang yg menghukumi secara tak benar padahal ia mengetahui mana yg benar, maka ia di neraka. Seorang hakim yg bodoh lalu menghancurkan hak-hak manusia, maka ia di neraka. Dan seorang hakim yg menghukumi dgn benar, maka ia masuk surga. [HR. Tirmidzi No.1244.)

6. Asadulloh Al Faruq, Hukum Acara Peradilan Islam ( Yogyakarta: PT Pustaka Yudistia, 2009), hlm. 4.
} 
SWT yang memerintahkan kepada beliau untuk menyelesaikan persengketaan yang timbul, yaitu Q.S 4: 65 . $^{7}$

Setelah dakwah Islam tersebar, maka Nabi Muhammad SAW memberi izin sebagian sahabatnya (untuk memutuskan hukum terhadap perkara yang mereka hadapi) karena jauhnya tempat, dan bahkan diizinkan juga di antara sahabatnya untuk memutuskan perkara di tempat Nabi berada, dan hal ini dimaksudkan sebagai pendidikan bagi sahabatnya tentang ijtihad,yang selanjutnya dikonsultasikan kepada Nabi Muhammad SAW. ${ }^{8}$ Dalam prakteknya Nabi Muhammad SAW memutuskan perkara berdasarkan wahyu yang diturunkanoleh Allah SWT kepadanya.

Sesudah Islam mulai tersebar, Rasulullah mengizinkan para sahabat memutuskan perkara sesuai dengan ketetapan Allah, sunah Rasul, ijtihad atau qiyas. Pedoman ini jelas kita peroleh dalam hadis Mu'adh bin Jaba $>1$ di waktu beliau diangkat menjadi gubernur dan hakim di Yaman. Nabi Muhammad SAW membenarkan para hakim mempergunakan qiyas untuk memutuskan perkara-perkara maupun sengketa, karena hukum-hukum al Qur'an yang telah turun pada prinsipnya hanya mengenai beberapa kejadian saja secara umum, demikian pula sabda-sabda Nabi dan petunjukpetunjuknya hanya mengandung hal-hal yang umum bukan secara terperinci

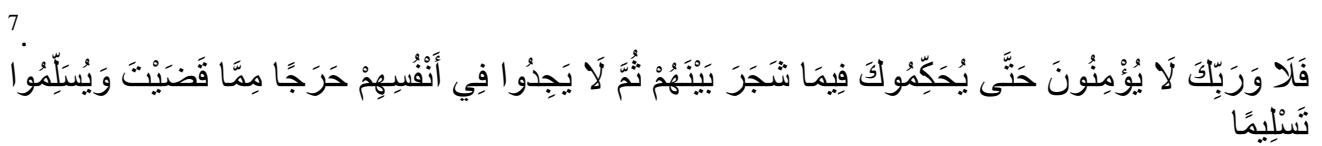
65. Maka demi Tuhanmu, mereka (pada hakekatnya) tidak beriman hingga mereka menjadikan kamu hakim terhadap perkara yang mereka perselisihkan, kemudian mereka tidak merasa dalam hati mereka sesuatu keberatan terhadap putusan yang kamu berikan, dan mereka menerima dengan sepenuhnya.

8 . HR Imam Tirmizi : Artinya: "Bahwa khalifah Usman Bin Affan pernah berkata kepada Abdullah Bin Umar: pergilah kemudian putuskanlah perkara diantara manusia, ia menjawab: hendaknya engkau bebaskan aku hai Amirul Mu'minin? Khalifah berkata: apakah gerangan yang menyebabkan engkau enggan (melaksanakan) itu, padahal ayahmu pernah melaksanakannya? Ia menjawab: sesungguhnya ayahku dahulu pernah (diserahi tugas) memutus perkara, tapi kalau iamenemui kesulitan, ia (langsung) bertanya kepada Rasulullah. 
yang terus menerus terjadinya di setiap masa dan tempat. Ciri khas peradilan pada masa Nabi Muhammad SAW setidaknya ada lima yaitu: ${ }^{9}$

a. Tidak ada pemisahan kekuasaan di bidang peradilan dengan kekuasaan di bidang lain,

b. Kekuasaan di bidang peradilan menyatu dengan kekuasaan di bidang

c. fatwa.

d. Hakim memiliki kemerdekaan dalam menetapkan hukum atas perkara-perkara yang dihadapkan kepadanya.

e. Nabi Muhammad SAW mendelegasikan kekuasaan di bidang peradilan kepada sahabat yang memiliki kemampuan secara cepat, tepat dan memiliki kejujuran untuk menyelesaikan persoalan yang dihadapkan kepadanya.

f. Belum terdapat lembaga pemasyarakatan (penjara) sebagaimana yang

g. dikenal di masa sekarang.

Di dalam literatur yang lain ditambahkan pula satu ciri khas di antara lima ciri khas yang disampaikan di atas, ciri khas itu adalah bahwa di masa Nabi Muhammad SAW telah dikenal adanya peninjauan kembali suatu keputusan hukum yang telah dijatuhkan dan hal itu secara praktis dilakukannya, karena apa yangterjadi itu menggambarkan semacam adanya keputusan dari pengadilan tingkat pertama di hadapan pengadilan yang lebih tinggi, sehingga ditinjau kembali perkara itu, kemudian keputusan itu ada kemungkinan akan dibatalkan atau diganti dengan keputusan yang baru. ${ }^{10}$

\section{Diskursus Hakim Perempuan Dalam Islam}

\footnotetext{
9. Atiyah Mushtafa Mushrifah, Qada fi al-Islam, (Beirut:Sharkah al-Sharq al-Awsat,t.t), hlm. 93.

10. Muhammad Salam Madkur, Peradilan Dalam Islam, (Surabaya:Bina Ilmu, 1993), hlm. 29
} 
Diskursus yang terkait dengan persoalan pemberdayaan perempuan serta emansipasi perempuan yang saat ini tengah menjadi topic pembahasan masyarakat dunia, termasuk masyarakat Muslim, seolah menjadi puncak dari perjalanan gelap kaum perempuan di masa lalu. Tidak hanya di Barat, hampir diseluruh penjuru dunia, perempuan di masa sebelum datangnya Islam tidak mendapatkan kedudukan yang setara dengan kaum laki-laki.

Secara normatif, ulama fikih klasik terbagi menjadi 3 kelompok yang saling berbeda pandangan tentang kedudukan perempuan sebagai hakim. Ketiga kelompok tersebut adalah:

Kelompok pertama, menyatakan perempuan tidak boleh menjadi hakim. Pendapat ini disuarakan oleh mayoritas ulama serta tokoh-tokoh dari mazhab Imam Malik, Imam al-Shafi' i, dan Imam Ahmad bin Hanbal. Alasan kelompok ini adalah pemahaman yang bersumber dari ayat al-Qur'an dalam Q.S 4:34, hadis riwayat Imam al-Bukhari, serta hadis riwayat Ibnu Majah yang menyatakan bahwa akal dan keberagamaan perempuan kurang jika dibandingkan laki-laki ${ }^{11}$. Imam al-Shafi'i dalam kitab al-Umm nya menyebutkan bahwa terdapat kekurangan dalam diri perempuan sehingga laki-laki lah yang dijadikan "qawwam" (pemimpin) termasuk dalam konteks menjadi hakim.

Persyaratan harus berjenis kelamin laki-laki menjadi syarat mutlak bagi kelompok ini, sehingga segala keputusan yang bertentangan dengan syarat ini maka akan ditolak, karena menurutnya kedudukan perempuan

11 ما رأيت من ناقصات عقل ودين أغلب للب الرجل الحازم من إحداكن فقيل يا رسول الله ما نقصان

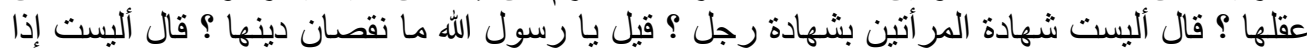
حاضت لم تصل ولم تصم ؟ $-6-$ 
dalam sistem peradilan sama kedudukannya seperti halnya al-Imamah alKubra. $^{12}$

Imam Al-Qurtubi menjadikan Q.S. An-Nisa' ayat 34 sebagai dalil bahwa perempuan tidak boleh menjadi hakim. Hal ini dipahami dengan kata "qawwam" atau pemimpin. Kata ini mempunyai tiga arti yaitu :1. hukkam (hakim), 2. Umara (penguasa), 3. Man yazku (orang yang berperang). ${ }^{13}$ Adanya klausul berjenis kelamin laki-laki masih menjadi syarat mutlak bagi pengikut mazhab imam Malik, al-Shafi'i dan Ahmad bin $\mathrm{H}$ \}anbal dalam menentukan boleh tidaknya seseorang menjadi hakim. Adapun kisah Ratu Balqis yang seringkali dijadikan dalil oleh kelompok yang memperbolehkan perempuan menjadi pemimpin, dibantah oleh kelompok pertama ini dengan alasan bahwa Ratu Balqis menjadi pemimpin ketika belum masuk Islam, sedangkan setelah masuk Islam dan dinikahi oleh Nabi Sulaiman maka seluruh kekuasaannya diserahkan kepada Nabi Sulaiman. Oleh karenanya menurut kelompok ini, tidak tepat apabila kisah Ratu Balqis dijadikan dalil. ${ }^{14}$

Demikian pula kisah tentang khalifah di dinasti Mamalik yang masih berada di bawah kekuasaan dinasti Abbasiyah. Ketika itu khalifah alMuntas\}ir billah mengirimkan calon pengganti khalifah yang ketika itu dijabat oleh seorang perempuan yang bernama Syajaratuddur yang

\footnotetext{
12. Ibnu Rushdi, Bidayah al-Mujtahid wa al-Nihayah al-Muqtasid,(Shirkah an-Nur,t.t), II, hlm. 678.

13. Syeikh Abdul Rauf Al- Singkili, Corak Pemikiran Hukum Islam : Studi Terhadap Kitab Mir'at al-Thullab Tentang Hakim Perempuan, (Banda Aceh: Yayasan Pena, 2008), hlm. 55.

14. Mohammad Ahmad Alkuran, "Tampering with Qur'anic True Meanings of Miracles",Asian Social Science, Vol. 9, No. 9, 2013,183, http://eresources.perpusnas.go.id/library.php? $i d=00001$ (Diakses 19 Mei 2015).
} 
merupakan putri dari khalifah Malik al-Salih. Pada akhirnya setelah 3 bulan menjabat posisi khalifah Syajaratuddur digantikan oleh Emir Izuddin ${ }^{15}$

Kelompok kedua, menyatakan bahwa perempuan boleh menjadi hakim dalam kasus-kasus tertentu. Kelompok ini dipelopori oleh Imam Hanafi yang terkenal dengan aliran rasional. Imam Hanafi berpendapat bahwa perempuan dapat menjadi hakim karena persaksiannya pun diterima. Oleh sebab persaksian perempuan diterima, maka ketika perempuan menjadi hakim pun maka hal tersebut dapat diterima. Namun demikian Imam Hanafi memberikan batasan kepada perempuan yang menjadi hakim untuk tidak menangani kasus hudud dan qisas. ${ }^{16}$ Di sisi lain mazhab Imam $\mathrm{H}$ \}anafi memberikan kelonggaran dengan membolehkan perempuan menjadi hakim untuk perkara muamalah. ${ }^{17}$

Argumentasi yang dikemukakan oleh Imam Hanafi beserta pengikutnya adalah terletak pada persoalan istinbat hukum, dimana selain menggunakan sumber utama al-Qur'an dan al-Sunnah, juga menggunakan metode fatwa-fatwa dari sahabat, qiyas, ijma', istihsan, dan al-'urf sebagai dasar dalam menentukan istinbat hukum. Dengan kata lain, Imam Hanafi menggunakan metode maslahat al-mursalah dan qiyas.

Kelompok ketiga adalah kelompok yang memperbolehkan perempuan menjadi hakim secara mutlak dalam semua kasus atau perkara. Tokoh pencetus faham ini adalah Ibnu Jarir al-Tabari, Abu Sa'id al-Hasan bin Abi Hasan Yasar al-Basri, serta mazhab Zahiri yang berbeda dengan dua pendapat sebelumnya, dimana mereka dengan tegas mengatakan kebolehan seorang perempuan menjadi hakim ketika telah dibolehkan menjadi mufti.

\footnotetext{
${ }^{15}$. Utari Maharany Barus, "Pemimpin Wanita dan Hakim Wanita Dalam Pandangan Islam", http://library.usu.ac.id/download/fh/perdata-utary\%20maharany.pdf.

16. Abi al-Mawahib 'Abdul Wahab bin Ahmad bin 'Ali al-Ansari, Al-Mizan al-Kubra, (Surabaya: Al Hidayah,t.t) II, hlm. 189.

17. Karen Bauer, "Debates on Women's Status as Judges and Witnesses in Post-Formative Islamic Law",Journal of the American Oriental Society130.1 , 2010, hlm. 3.
}

$-8-$ 
Menurut al-Tabari terdapat beberapa alasan tentang diperbolehkannya wanita menjadi seorang hakim yaitu sebagai berikut: ${ }^{18}$

a. Sahabiyah Samra' binti Nuhaik al-Asa'diyah bertugas dalam peradilan di Makkah pada masa Nabi Muhammad SAW.

b. Umar bin Khattab mengangkat Shifa binti Abi Sulaiman sebagai petugas hisbah di pasar Madinah.

c. Majalah al-Ahkam al-Hidayah berdasarkan mazhab Imam Hanaf i tidak menuntut seorang hakim harus laki-laki.

Dalam konteks ulama kontemporer, yang mendukung kebolehan perempuan menjadi hakim dalam semua perkara, termasuk hudud maupun qisas antara lain adalah diwakili oleh tokoh-tokoh seperti Muhammad Abduh, Nasr Hamid Abu Zaid dan M. Quraish Shihab. Mereka mendasarkan atas dalil yang sama namun dengan cara pandang yang berbeda yakni lebih tematik dan kontekstual dalam menafsirkan teks keagamaan serta mempertimbangkan perubahan kondisi sosial politik dan budaya, mereka membolehkan perempuan menjadi hakim untuk semua perkara. ${ }^{19}$

Berdasarkan perbedaan pandangan diantara ulama tersebut, maka sangatlah menarik untuk dikaji implementasi di negara Indonesia terhadap persoalan hakim perempuan mengingat mayoritas penduduk Indonesia adalah bermazhab al-Shafi'i. Namun demikian tidak adanya keberpihakan negara terhadap salah satu mazhab-mazhab dalam Islam menjadikan hukum Islam di Indonesia menjadi lebih fleksibel mengikuti perkembangan perbedaan pandangan tersebut. Salah satu contohnya adalah dalam topic pembahasan artikel ini.

18. Mohd Quzaid al Fitry B. Termiji, "Studi Komparatif tentang Kedudukan Hakim Wanita Antara Mahkamah Syariah dan Sivil di Malaysia",Al-Risalah, Jurnal Kajian Hukum Islam , Vol. 12, No. 1, Desember 2012, hlm. 274.

19 . Djazimah Muqoddas, Kontroversi Hakim Perempuan... 


\section{Hakim Perempuan Dalam Sistem Peradilan Agama di Indonesia}

Negara Indonesia merupakan salah satu negara yang dapat dianggap sebagai pelopor diberikannya kesempatan kepada perempuan untuk menjadi hakim. ${ }^{20}$ Sejak tahun 1956, lembaga peradilan di Indonesia telah mengangkat hakim perempuan, ${ }^{21}$ tepatnya di masa KH Moehammad Djoenaidi menjabat Kepala Biro Peradilan Agama, sekitar 20 perempuan yang merupakan peserta kursus penasihat perkawinan yang diselenggarakan oleh Kowani Biro Peradilan Agama dan Jawatan Urusan Agama. Pengangkatan beberapa perempuan sebagai anggota hakim pada peradilan agama juga dicatat oleh Daniel S.Lev, yakni pada tahun 1974 terdapat 15 anggota honorer dan satu anggota tetap di Tegal.

Dalam perkembangannya pada tahun 1975 Departemen Agama merekrut para sarjana syari'ah untuk diangkat sebagai hakim pada Pengadilan Agama. Sehubungan dengan hal ini banyak juga para sarjana perempuan mengajukan permohonan untuk diangkat menjadi hakim pada Pengadilan Agama. Terhadap hal ini timbul pro dan kontra, sehingga Menteri Agama R.I. menyarankan untuk dibicarakan di dalam sidang Alim Ulama Terbatas pada tanggal 14-17 Juli 1975 di Jakarta. Dalam musyawarah tersebut disimpulkan antara lain; (1) hakim perempuan dalam pengadilan adalah masalah perselisihan di kalangan mujtahidin; (2) adanya perempuan yang menjadi hakim pada Pengadilan Agama yang sudah berjalan beberapa waktu yang lalu adalah sesuai kemaslahatan; (3) oleh karena itu pengangkatan perempuan pada jabatan hakim Pengadilan Agama dapat dibenarkan.

\footnotetext{
${ }^{20}$. Euis Nurlaelawati dan Arskal Salim, "Gendering The Islamic Judiciary: Female Judges in the Religious Courts of Indonesia”, Al-Jami'ah, Vol.51, No.2, 2013, hlm. 248. 21 http://www.patanjungbalai.net/index.php?option=com_content $\&$ view $=$ article $\& i d=338:$ haki m-perempuan-di-peradilan-agama-riwayatmu-kini.$$
-10-
$$

Al Marhalah : Jurnal Pendidikan Islam. Volume. 1, No.2 November 2017 
Berkenaan dengan hal tersebut, apabila kita lihat kenyataan yang ada dan berlaku sekarang ini, perempuan telah disejajarkan dengan pria dalam hal eksistensinya sebagai hakim di Pengadilan Agama. Terlebih lagi setelah adanya Undang-Undang No. 7 tahun 1989 tentang Peradilan Agama, peluang perempuan untuk menjadi hakim dan peran yang dapat mereka lakukan setelah menjabat jabatan hakim benar-benar telah disamakan dengan pria. Hal ini dapat dipahami dari maksud pasal 13 ayat 1 Undang-Undang No. 7 tahun 1989 tentang Peradilan Agama, yakni:

\section{Pasal 13}

(1) Untuk dapat diangkat menjadi Hakim pada Pengadilan Agama, seorang calon harus memenuhi syarat-syarat sebagai berikut:

a. warga negara Indonesia;

b. beragama Islam;

c. bertaqwa kepada Tuhan Yang Maha Esa;

d. setia kepada Pancasila dan Undang-Undang Dasar 1945;

e. bukan bekas anggota organisasi terlarang Partai Komunis Indonesia, termasuk organisasi massanya atau bukan seseorang yang terlibat langsung ataupun tak langsung dalam "Gerakan Kontra Revolusi G.30.S/PKI", atau organisasi terlarang yang lain;

f. pegawai negeri;

g. sarjana syari'ah atau sarjana hukum yang menguasai hukum Islam;

h. berumur serendah-rendahnya 25 (dua puluh lima) tahun;

i. berwibawa, jujur, adil, dan berkelakuan tidak tercela.

Ketentuan tersebut dipertegas lagi pada pasal 13 ayat 1 Undang-Undang No. 3 tahun 2006 yaitu tentang perubahan Undang-undang No.7 Tahun 1989 tentang Peradilan Agama disebutkan bahwa: 


\section{Pasal 13}

(1)Untuk dapat diangkat sebagai calon hakim pengadilan agama, seseorang harus memenuhi syarat sebagai berikut:

a. warga negara Indonesia;

b. beragama Islam;

c. bertaqwa kepada Tuhan Yang Maha Esa;

d. setia kepada Pancasila dan Undang-Undang Dasar Negara Republik Indonesia Tahun 1945;

e. sarjana syariah dan/atau sarjana hukum yang menguasai hukum Islam;

f. sehat jasmani dan rohani;

g. berwibawa, jujur, adil, dan berkelakuan tidak tercela; dan

h. bukan bekas anggota organisasi terlarang Partai Komunis Indonesia termasuk organisasi massanya, atau bukan orang yang terlibat langsung dalam Gerakan 30 September/Partai Komunis Indonesia.

Persyaratan tersebut datang dalam bentuk umum tanpa menyinggung asas personalitas yang didasarkan pada jenis kelamin tertentu. Sebagai konsekuensinya dapat difahami bahwa baik pria maupun perempuan mempunyai peluang yang sama untuk menjadi hakim agama. ${ }^{22}$

Berdasarkan data dari Direktorat Jenderal Badan Peradilan Agama (Badilag) Mahkamah Agung tahun 2011, jumlah hakim perempuan tidak lebih dari $21 \%$ dari total hakim yang bertugas di Pengadilan Agama.

Tabel perbandingan hakim laki-laki dan perempuan

\begin{tabular}{l|l|l|l} 
No Jenis Kelamin & Tingkat & Tingkat Banding & Jumlah
\end{tabular}

22. Fatimah, "Hakim Agama Perempuan di Pengadilan Agama Medan (Studi tentang Peluang dan Hambatan Dalam Peningkatan Karir)", Jurnal Penelitian: MedanAgama, Edisi $8 \quad$ Desember 2008, 5 , http://www.jurnalmedanagama.org/index.php/medag/article/viewFile/5/2. (Diakses $19 \mathrm{Mei}$ 2015). 


\begin{tabular}{|l|l|l|l|l|}
\hline & & Pertama & & \\
\hline 1. & Laki-laki & 2.442 & 471 & 2.913 \\
\hline 2. & Perempuan & 738 & 36 & 774 \\
\hline & Jumlah & 3.180 & 507 & 3.687 \\
\hline
\end{tabular}

Sumber : http://www.pa-tanjungbalai.net

Perbandingan yang tidak seimbang ini,secara langsung maupun ataupun tidak langsung berimbas pada kualitas putusan yang dihasilkan oleh para hakim perempuan. Dalam kasus mediasi perceraian, keberadaan hakim perempuan memang dirasakan dapat memberi manfaat yang lebih banyak bagi pihak yang berperkara jika dibandingkan dengan hakim laki-laki. ${ }^{23}$ Selain itu, tingginya sensifitas hakim perempuan ikut mempengaruhi alur pertimbangan hakim tersebut dalam membuat putusan. Hal ini tidak hanya menjadikan subjektifitas namun juga membuat kurang berkualitasnya putusan tersebut. ${ }^{24}$

\section{Perubahan Hukum dan Perubahan Sosial}

Manusia merupakan pribadi dengan identitas diri yang sangat kompleks. Ia adalah makhluk sosial yang mesti hidup bermasyarakat dan terikat dengan norma masyarakat, namun ia juga makhluk beragama yang terikat dengan hukum-hukum agama. Haruskah antara norma masyarakat dan hukum agama saling dibenturkan? Selain itu, kehidupan sosial itu dinamis dan akan selalu mengalami perubahan sesuai dengan tuntutan zaman. Hukum Islam tidak dimaksudkan untuk mengubah kondisi sosial yang ada, sebaliknya ia diterapkan sejalan dengannya. Oleh karenanya, dalam Islam dikenal sebuah kaidah yang sangat populer yang berbunyi:berubahnya suatu hukum hendaknya disesuaikan dengan situasi, kondisi, waktu, dan tempatnya.

\footnotetext{
23. Shuai, Wei; Xin, Xin, "Does Gender Play a Role in Divorce Mediation?: Working Pattern of Women Judges in China", Asian Journal of Women's Studies,19.3 (2013), hlm. 150.

${ }^{24}$. Euis Nurlaelawati dan Arskal Salim, “Gendering The Islamic Judiciary...
} 


\section{Muhammad Aiz}

Dengan menerapkan kaidah hukum Islam tersebut, kelompok yang memperbolehkan perempuan menjadi hakim mencoba melihat status hukum hakim perempuan secara lebih jernih. Kelompok ini sependapat dengan teori perubahan hukum yang dikemukakan oleh Ibnu Qayyim al-Jauziyyah yang menjustifikasi kedudukan hukum perempuan menjadi hakim di pengadilan. Ibnu Qayyim mengatakan bahwa ajaran Islam menggaransi persamaan derajat antara laki-laki dan perempuan. $^{25}$ Laki-laki dan perempuan mempunyai peran yang sama di ranah publik. Dengan demikian tak ada alasan untuk melarang perempuan menjadi hakim baik untuk urusan perdata maupun pidana. Kaidah di atas sudah cukup untuk dijadikan pegangan hukum bahwa terdapat hubungan yang positif antara hukum Islam dan kondisi masyarakat. Perubahan masyarakat akan berpengaruh terhadap perubahan hukum. Islam mengakui bahwa apa yang diciptakan oleh manusia sebagai kebaikan. Sehingga ketika kondisi kaum perempuan sudah berubah karena banyak yang berpendidikan tinggi dan banyak yang belajar hukum, tak ada alasan untuk menolak keabsahan hakim perempuan baik dilihat dari sudut pandang hukum Islam maupun hukum negara. ${ }^{26}$

Di Indonesia sendiri teori perubahan hukum dan perubahan sosial tersebut sudah diaplikasikan karena jika kita lihat pada masa sebelum kemerdekaan, perempuan belum mendapat kesempatan untuk menjadi hakim di Peradilan Agama. Baru kemudian setelah dikeluarkannya UU Peradilan Agama No. 7 Tahun 1989, perempuan mempunyai landasan hukum yang jelas dan mempunyai kesempatan yang sama dengan laki-laki untuk menjadi hakim di Peradilan Agama. Meskipun demikian kesempatan itu belum dimanfaatkan secara maksimal. Karena secara kuantitas maupun kualitas hakim perempuan masih ketinggalan jauh dibandingkan hakim laki-laki. Hal ini karena belum ada pembinaan yang serius terhadap caloncalon hakim perempuan.

${ }^{25}$. Q.S.4:124

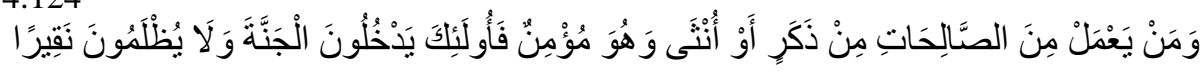

124. Barangsiapa yang mengerjakan amal-amal saleh, baik laki-laki maupun wanita sedang ia orang yang beriman, Maka mereka itu masuk ke dalam surga dan mereka tidak dianiaya walau sedikitpun.

${ }^{26}$. Djazimah Muqoddas, Kontroversi Hakim Perempuan... 
Salah satu kaidah usul al-fiqh yang disebutkan oleh Ibnu al-Qayyim al-Jawziyah :

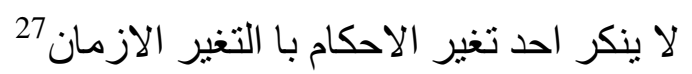

Seingkali menjadi landasan dari terjadinya perubahan hukum yang disebabkan oleh adanya perubahan waktu dan masyarakat. Namun sesungguhnya kaidah ini tidak terlalu kuat, bahkan sering disalah fahami, seakan-akan faktor satu-satunya yang mengubah hukum adalah zaman atau semisalnya seperti tempat, kondisi, dan adat. Padahal, dengan mencermati kitab I'lâm al-Muwaqqi în, karya Ibnu Qayyim Al-Jawziyah, yang sering dirujuk sebagai sumber kaidah ini, akan jelas bahwa duduk perkaranya tidaklah demikian. Yang benar, perubahan hukum itu terjadi karena adanya nas itu sendiri, yang menunjukkan perubahan hukum, bukan karena faktor waktu, zaman, dan sebagainya. Waktu dan tempat tidak dapat mengubah hukum jika tidak ada nas yang menunjukkan perubahan hukum. Ibnu Qayyim mencontohkan, Nabi Muhammad SAW. tidak menjatuhkan hukum potong tangan pada saat perang. Tindakan Nabi itu bukan karena perang itu sendiri, tetapi karena ada nas lain yang menetapkan tidak dilaksanakannya hukum potong tangan untuk orang yang mengambil bagian harta ghanimah pada saat perang sebelum dibagi-bagikan. ${ }^{28}$

Melihat adanya bantahan terhadap kaidah usul al-fiqh tersebut, menjadikan keberadaan hakim perempuan dalam konteks perubahan zaman

27. Abdul Karim Zaidani, Al-Wajiz fi Usul al-Fiqh, (Lebanon:Al-Muassasah alRisalah, 1996), hlm. 258.

28. Q.S.3:161.

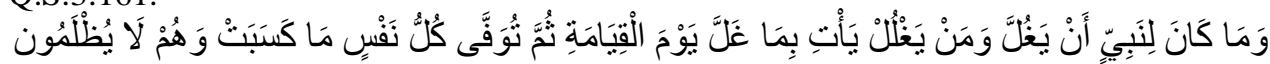
161. tidak mungkin seorang Nabi berkhianat dalam urusan harta rampasan perang. Barangsiapa yang berkhianat dalam urusan rampasan perang itu, Maka pada hari kiamat ia akan datang membawa apa yang dikhianatkannya itu, kemudian tiap-tiap diri akan diberi pembalasan tentang apa yang ia kerjakan dengan (pembalasan) setimpal, sedang mereka tidak dianiaya.

29. Q.S.2:282 
yang telah menjadikan perempuan lebih terampil harus mampu dibarengi dengan argumentasi valid yang bersumber dari nas al-Qur'an maupun hadis. Oleh karenanya metode qiyas yang dipergunakan oleh Imam Hanafi maupun al-Tabari, harus dibarengi pula dengan dalil yang bersumber dari nas yakni mengqiyas dengan diterimanya persaksian perempuan. ${ }^{29}$

\section{Keberadaan Hakim Perempuan di Negara Muslim}

Kedudukan perempuan di berbagai negara muslim, sesungguhnya memiliki perbedaan apabila dikaitkan dengan kemungkinan untuk menjadi seorang hakim. Hal ini dapat dimaklumi karena adanya perbedaan pandangan yang sangat kontras sebagaimana telah diuaraikan dibagian sebelumnya.

Indonesia merupakan negara muslim yang sangat positif dalam memberikan kesempatan bagi kaum perempuan untuk menjadi hakim. Kenyataan ini menunjukan adanya pergeseran pemahaman mazhab fiqih, yang semula didominasi faham mazhab Shafi'iyyah menjadi lebih kearah metodologis nya, yakni manhaji. Metode manhaji yaitu menyelesaikan masalah hukum dengan mengikuti jalan pikiran dan kaidah penetapan hukum yang telah disusun oleh imam mazhab. Prosedur operasional metode manhaji adalah dengan mempraktekan qawa'id al-usuliyyah dan qawa'id alfiqhiyyah. ${ }^{30}$ Oleh karenanya tidaklah mengherankan sejak tahun 1956 telah mulai diangkatnya perempuan menjadi hakim di Peradilan Agama.

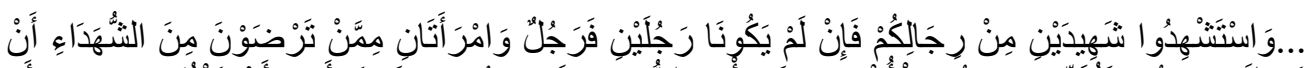

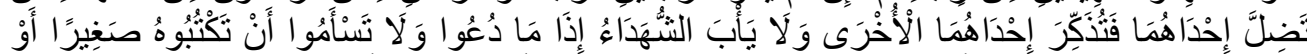

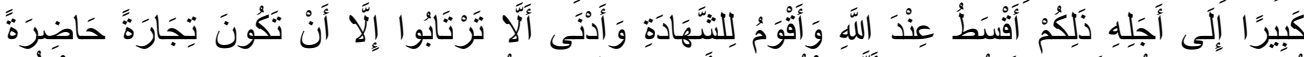

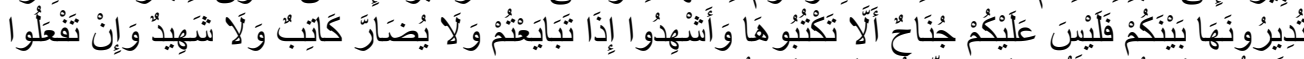

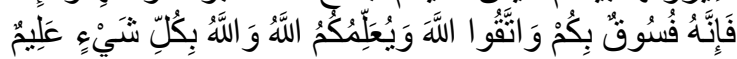
dan persaksikanlah dengan dua orang saksi dari orang-orang lelaki (diantaramu). jika tak ada dua oang lelaki, Maka (boleh) seorang lelaki dan dua orang perempuan dari saksi-saksi yang kamu ridhai, supaya jika seorang lupa Maka yang seorang mengingatkannya.

30. Aziz Masyhuri, Masalah Keagamaan NU, (Surabaya:PP.RMI dan Dinamika Press,1997), hlm. 365-367. 
Di negara-negara muslim lainnya pun keberadaan hakim perempuan mulai mendapatkan kesempatan meskipun perbandingannya dengan hakim laki-laki masih tergolong kalah banyak di lihat dari segi kuantitas. Negaranegara Arab yang telah menerima perempuan menjadi hakim diantaranya adalah Sudan, Maroko, Suriah, Lebanon, Yaman. Serta Iran yang baru memberikan kesempatan hakim perempuan di era Ayatulloh Sayid Ali Khamenei dan Presiden Mohammad Khatami ${ }^{31}$ Malaysia pun pada periode terakhir ini telah memberikan kesempatan bagi perempuan untuk menjadi hakim. ${ }^{32}$ Negara India juga telah memberikan hak bagi perempuan untuk menjadi hakim. ${ }^{33}$

\section{Kesimpulan}

Umat Islam hendaknya menyadari bahwa al-Qur'a $>n$ adalah sebuah teks yang harus dibaca secara kontekstual, yaitu dengan memahami konteks historis di mana al-Qur'a>n diturunkan. Membaca al-Qur'a $>n$ secara kontekstual akan membawa kepada penghayatan terhadap pesan-pesan moral yang bersifat universal, seperti keadilan, kesamaan hak, penghormatan terhadap kemanusiaan, cinta kasih, dan kebebasan. Pesan hakiki inilah yang sesungguhnya merupakan benang merah yang menjadi penghubung eksistensi umat manusia dari satu generasi ke generasi berikutnya, dari kurun waktu ke kurun berikutnya. ${ }^{34}$

\footnotetext{
31. Dima Amr, "Legal Scholars, Religious Experts Debate Islam's Position on Women Judges",Middle East News Online [Durham] 01 Oct 2000: N/A.

32. Abdussalam Muhammad Shukri, Musa Yusuf Owoyemi, "Sister in Islam's Quest for the Reinterpretation of the Qur'an and Hadith: An Analysis of Their Views on Quality, Women Judges, and Polygamy", Kajian Malaysia, Vol. 32, No.1, 2014, hlm. 55-80.

33. Sabiha Hussain, Shariat Courts and Question of Women's Right in India", Pakistan Journal of Women's Studies: Alam-e-Niswan Vol.14, No.2, 2007, hlm. 101.

34. Siti Musdah Mulia, Muslimah Reformis: Perempuan Pembaharu Keagamaan, cet. ke-1 (Bandung: Mizan, 2005), hlm. 304-306.
} 
Berdasarkan hal tersebut, maka segala perbuatan manusia, baik lakilaki maupun perempuan yang didasari atas kemampuan untuk berbuat kebajikan maka sesungguhnya tidaklah tepat untuk dihalangi, apalagi jika dalil-dalil yang diargumentasikan masih terdapat perbedaan pendapat dikalangan ulama dalam menyikapinya.

\section{Daftar Pustaka}

Al-Qur'an Terjemahan (Kementerian Agama R.I).

Al-Ansari, Abi al-Mawahib 'Abdul Wahab bin Ahmad bin 'Ali, Al-Mizan $a l-$ Kubra, (Surabaya: Al Hidayah,t.t) II.

Amr, Dima , "Legal Scholars, Religious Experts Debate Islam's Position on Women Judges",Middle East News Online [Durham] 01 Oct 2000: N/A.

Barus, Utari Maharany, "Pemimpin Wanita dan Hakim Wanita Dalam Pandangan Islam", http://library.usu.ac.id/download/fh/perdatautary\%20maharany.pdf.

Bauer, Karen, "Debates on Women's Status as Judges and Witnesses in PostFormative Islamic Law", Journal of the American Oriental Society $130.1,2010$.

Al Faruq, Asadulloh, Hukum Acara Peradilan Islam ( Yogyakarta: PT Pustaka Yudistira, 2009).

Fatimah, "Hakim Agama Perempuan di Pengadilan Agama Medan (Studi tentang Peluang dan Hambatan Dalam Peningkatan Karir)", Jurnal Penelitian: MedanAgama, Edisi 8 Desember 2008. http://www.jurnalmedanagama.org/index.php/medag/article/viewF ile/5/2. (Diakses 19 Mei 2015).

Hussain, Sabihan, Shariat Courts and Question of Women's Right in India", Pakistan Journal of Women's Studies: Alam-e-Niswan Vol.14, No.2, 2007.

Al-Kuran, Mohammad Ahmad, "Tampering with Qur'anic True Meanings of Miracles",Asian Social Science, Vol. 9, No. 9, 2013,183, http://eresources.perpusnas.go.id/library.php?id=00001 (Diakses 19 Mei 2015). 
Madkur, Muhammad Salam, Peradilan Dalam Islam, (Surabaya:Bina Ilmu, 1993).

Masyhuri, Aziz, Masalah Keagamaan NU, (Surabaya:PP.RMI dan Dinamika Press, 1997).

Mulia,Siti Musdah, Muslimah Reformis: Perempuan Pembaharu Keagamaan, cet. ke-1 (Bandung: Mizan, 2005).

Mushtafa Mushrifah, Atiyah, Qada fi al-Islam, (Beirut:Sharkah al-Sharq alAwsat \},t.t).

Muqoddas, Djazimah, Kontroversi Hakim Perempuan pada Peradilan Islam di Negara-negara Muslim, (Yogyakarta: LKis, 2011).

Nasution, Khoirudin, Fazlur Rahman tentang Wanita, (Yogyakarta:Tazzafa,2002).

Nurlaelawati,Euis dan Salim, Arskal , "Gendering The Islamic Judiciary: Female Judges in the Religious Courts of Indonesia", Al-Jami'ah, Vol.51, No.2, 2013.

Rushdi,Ibnu, Bidayah al-Mujtahid wa al-Nihayah al-Muqtasid, (Shirkah an-Nur,t.t),II.

Shuai, Wei; Xin, Xin, "Does Gender Play a Role in Divorce Mediation?: Working Pattern of Women Judges in China", Asian Journal of Women's Studies, 19.3 (2013).

Shukri,Abdussalam Muhammad Shukri, Musa Yusuf Owoyemi, "Sister in Islam's Quest for the Reinterpretation of the Qur'an and Hadith: An Analysis of Their Views on Quality, Women Judges, and Polygamy”, Kajian Malaysia, Vol. 32, No.1, 2014, 55-80.

Al-Singkili, Syeikh Abdul Rauf, Corak Pemikiran Hukum Islam : Studi Terhadap Kitab Mir'at al-Thullab Tentang Hakim Perempuan, (Banda Aceh: Yayasan Pena, 2008).

Termiji,Mohd Quzaid al Fitry B., "Studi Komparatif tentang Kedudukan Hakim Wanita Antara Mahkamah Syariah dan Sivil di Malaysia",Al-Risalah, Jurnal Kajian Hukum Islam, Vol. 12, No. 1, Desember 2012.

www.patanjungbalai.net/index.php?option=com_content $\&$ view=article\&id $=338: \mathrm{h}$ akim-perempuan-di-peradilan-agama-riwayatmu-kini. 
Muhammad Aiz

Zaidani, Abdul Karim, Al-Wajiz fi Usul al-Fiqh, (Lebanon:Al-Muassasah al-Risalah, 1996). 